\title{
Ways in which Learning Spaces Mediate Learning and Assessment
}

\section{Helen Bound and Arthur Chia}

In this article we consider learning spaces as the relations between the practices within the space; the material things such as tools, the ways of thinking, the discourses, the doings, sayings and historicity of these practices, the individual biographies of those participating in the learning space. Additionally learning spaces interact with; indeed have embedded within them doings and sayings, discourses, affordances and constraints of the contexts which are also constituted by these dynamic interactions. We use two case studies from a research project conducted in Singapore on, 'Assessment for the changing nature of work' to explore how the learning spaces mediate learning and assessment.

Key words: assessment, work, learning spaces,

\section{Introduction}

In the literature and amongst various groups of practitioners, the discourse of learning has shifted beyond metaphors (Sfard, 1998) of acquisition (and transfer), and in some instances beyond participation. Such a shift enables the questioning of long-held assumptions such as learning as a purely individual and cognitive processes, separation of work and learning, the privileging of content and setting up dichotomies between mind-body and knowledge and practice evident in classifying content into knowledge, skills and attitudes. We argue that learning is mediated by, through and within a context, not as separate from it. But it is the participation metaphor that is of particular interest for this Article. Building on and moving beyond the participation metaphor of learning the idea of 'learning space' or thinking about learning spatially conceptualises learning as socially situated in contexts that provide affordances for learners to integrate learning and work and to achieve membership in work cultures and/or communities of practice. This holistic 
understanding of 'space' invites us to consider the relational aspects of learning that include how work and learning are mutually constitutive in practice; the dynamic nature of context encapsulated in the notion of "changing nature of work", and the emergence and integrated-ness of learning. In using a practice lens we consider its contribution to our understanding of learning and assessment within learning spaces.

Relational aspects of work and learning within and between learning spaces is the focus of this article. We use data and findings about learning and assessment practices based on two semi-ethnographic case studies to highlight some dimensions of assessment as they occur within learning spaces at, through and for work. These cases are based on a research study we conducted in Singapore involving six diverse case studies (explained later in the article). In the process of exploring the relational aspects of learning spaces we also question and critique common understandings of assessment as separate from learning and as separate from work.

We commence the article with a brief explanation of the case studies to provide some context for when we refer to them later in the article; additionally we layout our working assumptions about assessment and learning. We unpack our understanding of learning spaces through drawing on data from a number of our case studies and conclude by drawing together the points we have made about how learning spaces mediate assessment practices and what the implications may be.

\section{Why assessment and learning spaces?}

The case studies are drawn from our project, "Assessment for the changing nature of work" (Bound, Chia \& Karmel, 2016). This research project addresses how assessment design and practices can meet changing policy directions and workforce development needs in Singapore.

\section{New policy initiatives}

It responds to government policy, economic and labour market changes, changes in the continuing education and training (CET) industry sector (closest equivalent is vocational education and training (VET)); recent changes in government policy were also an impetus for this project. In 2015 SkillsFuture became a major workforce development policy, placing a focus (amongst other strategic thrusts) on what Singapore's Deputy Prime Minister calls "workplace-based learning" (Shanmugaratnam, 2014). This new emphasis - a major shift from delivering 
training for CET via classrooms (Bound \& Lin, 2010) - requires a very considerable rethinking of learning and assessment for CET professionals, training providers and institutes of higher learning. Other reasons for the project include that Singapore's CET practitioners have long been looking for alternative approaches to assessment where the practice of teaching and learning for the test if oft observed. And, of course as the project title indicates there is the changing nature of work.

SkillsFuture is in part driven by changes in work and in labour markets in response to global shifts in capital and investment around the globe. Prime Minister Lee Hsien Loong announced in October 2015 that the Committee on "The Future Economy" will "study how to create opportunities and move faster towards higher skills, innovation and productivity" (Straits Times 18 October 2015, B1).

\section{Changing nature of work}

The increased sense of urgency to move to "higher skills, innovation and productivity" is but one of many pressures faced by both employers and workers. The hollowing out of the middle (Brown, Lauder \& Ashton, 2011), the growth of non-permanent work (Bound, Sadik \& Karmel, 2015), and technological change can be added to the list. Multiple career changes (of a minor and/or major nature) and the subsequent changes and requirement for learning, developing new skills and adapting to often rapid changes in management and cultures are also part of the landscape of work. These issues are seemingly far removed from learning and assessment, but learning and assessment can be one lever to prepare learners for unknown futures, preferably in ways that are also beyond work.

When we consider "the changing nature of work" we also consider that assessment can be designed and practiced in such a way that it can help prepare people, not just for a job or work, but for an evolving engagement in work that may not yet be known. Technological change, changes in forms of production, merges, movement of capital and outsourcing resulting in a variety of forms of nonpermanent work are now very much part of the landscape of work. Different forms of production (Victor \& Boynton, 1998; Engeström, 2004) require different skill sets that are not necessarily stable. In Singapore over $70 \%$ of jobs require a range of specific generic skills; other generic skills such as teamwork, planning and problem solving are utilised by most industries (Sung et al, 2010). Deming (2015) suggests that employment and wage growth is strongest in jobs that require high levels of both cognitive and social skills. Generic skills are becoming increasingly important; important not only because they are an indelible part of our work, but also because they are necessary in negotiating transitions. Whether it is jobs that existed many decades ago or jobs that no longer exist or that will exist in the future, what 
constitutes professional practice in these jobs has evolved along with advancements in knowledge and technology. It is no surprise that the nature of work is changing it has always been changing. What is, perhaps, surprising is that people are now becoming concerned over the adequacy of educational legacies in helping prepare people for this changing nature of work. Assessment and how we understand and use it is an important aspect of this new look at education in relation to work.

\section{Using a practice lens}

This rationale begs the question of how we understand learning and assessment.

When we understand learning spaces as relational, dynamic (ibid) and inclusive of practices (Schatzki, 2012) it becomes evident that learning is far more than acquisition and also more than as represented by Sfard's participation metaphor (1998). A practice lens enables us to strongly connect with our understanding of the changing nature of work. That is, as practices are emergent, not stable, so we understand the world of work to be constantly emergent. We conceive learning as an ongoing process; the individual and collectives can reproduce social relations and practices or change practices (perhaps in quite minute ways) as they make decisions, and take action within everyday routines (Reckwitz, 2002). Thus it is human action that gives meaning to different spaces. Within these different learning spaces and in the process of engaging in work practices we are constantly in the process of 'becoming' an engineer, a cook, a doctor and so on, albeit within the particular circumstances of the work. That is, knowledge, values and skills are not separate from the context of practice (Zukas \& Kilminster, 2012). Identity (as a cook, a doctor, a firefighter, a leader, for example) and agency for learning make sense when we understand that knowledge is not static, that practices are emergent, and generate their own understandings and is relational, dynamic and provisional (Fenwick, 2004; Fenwick, 2000). Agency for learning is mediated by individual sense making of the context, as the context is mediated by the actions of individuals and groups, informing "ways of knowing, doing, and feeling" or in other words "a way of being" (Edwards \& Usher, 1996).

So what is a "practice"? A practice is a "constellation of different people's activities... it embraces multiple people. The activities that compose it... are organised... a practice is an open-ended, spatially-temporally dispersed nexus of doings and sayings" (Schatzki, 2012, pp.13-14). It is inclusive of rules, understandings, resources, purposes, material 'things' and the relations between them. Hager, Lee and Reich (2012) outline five principles for theorising professional practice; practice as knowledgeable action, as embodied and materially mediated 
doings and saying, as relational, as evolved in historical and social contexts, power relations, and as emergent (p.8).

Conceiving of learning spaces as constituting practices, as relational, dynamic and emergent enables learning and assessment that is holistic and authentic. Using this lens we understand learning as more than participatory, as through a practice lens we understand that relations between agent and artefacts, tools, ways of knowing and doing, procedure and policies and all that make up the spaces of work, contribute to, are resources, and prompts for learning. Learning is deeply embedded in the spaces of work where work is both constituted by and constituting of learning. We argue below that assessment too, in the form of formative assessment is also deeply embedded in the spaces of work as feedback is engaged in and received constantly and through multiple sources. Such an understanding of learning and assessment challenges the idea of learning as an activity distinct/separate from other kinds of activities. Instead of boundaries and demarcated spaces, we posit the idea of work and learning as mutually constitutive rather than something contained within prescribed entities such as individuals and institutions.

\section{What is assessment?}

In keeping with the acquisition metaphor of learning, assessment has traditionally been considered in terms of measurement of the learning of the individual and as being objective and is done to learners. We take a different stance, one in keeping with our focus on the changing nature of work and the complex realities of assessment for, in and through work. We understand assessment as a process of making judgments; assessment is done with learners; in making this argument we recognise learning as a process with intentional goals. Judgments are made over time from multiple sources based on multiple forms of evidence. Assessment is a diverse and multifaceted range of phenomena, activities, systems and actors working within and across multiple contexts that contributes to learners' constant process of 'becoming' - a process that never ends.

For some time now assessment has been discussed in terms of assessment of learning (summative), for learning (formative) and as learning (see Earl, 2003). As a point of reference we define here what we mean by these terms. Assessment as learning is an aspect of sustainable assessment (Boud, 2010), so we capture it within our understanding of sustainable assessment. Summative assessment, sometimes referred to as assessment of learning, is what most people think of when they say 'assessment'. This is no doubt because the purpose of summative assessment is to certify the achievement or progress in learning. It is typically conducted at the end 
of a course or a programme (Earl, 2003). Summative assessment has a long history of being 'what counts' in gaining a qualification or some kind of certification. Formative assessment, or assessment for learning, focuses on participants' learning, helping them to know how to improve (Gardner, 2012). Participants need continuous information from a variety of sources about their learning; information that informs what they are succeeding at, and where they should put their efforts to improve and strategies for moving forward (Berry, 2008). Assessment for learning does not necessarily include grading, assigning marks or noting the learner as competent or not yet competent. Feedback is a critical aspect of assessment for learning. The focus in more recent work on feedback is on "the contribution of others to learning through assessment, and repositioning the notion of feedback not as an act of information giving to students, but as a co-productive process in which both students and others have key roles to play (Boud \& Soler, 2016, p.403). Sustainable assessment equips learners not just for meeting, but prepares them for what might be required in the future, after graduation. Sustainable assessment includes "the capacity to evaluate evidence, appraise situations and circumstances astutely, to draw sound conclusions and act in accordance with this analysis" (Boud \& Soler, 2016, p.19). Key elements of developing informed judgment from the perspective of the students include: (1) identifying oneself as an active learner; (2) identifying one's own level of knowledge and the gaps in this; (3) practising testing and judging; (4) developing these skills over time; and (5) embodying reflexivity and commitment. Sustainable assessment demands that learners make conscious comparisons between self-assessments and assessments by teachers, peers and other stakeholders, and that responsibility for the assessment process must gradually shift from the teacher to the students, because, after graduation, people themselves need to drive their own learning (Boud \& Soler, 2016).

\section{The six case studies}

What follows is a brief explanation of the case studies. We deliberately set out to identify a diverse range of cases in terms of assessment practices, types of providers, range of spaces in which assessment took place (classroom, work and e-spaces), and different types of accreditation frameworks. The list of cases is set out in Table 1 . The commonalities between these cases are that they all involve both formal (structured) and informal assessment practices; they are applied, in that they are preparing people for work compared to general education; and the programmes are strongly influenced and validated by industry standards. We focused on assessment 
practices that leverage on the opportunities and affordances of work and industry expectations in order to help prepare people for their futures.

\begin{tabular}{|c|c|c|c|c|}
\hline Case & $\begin{array}{c}\text { Certified } \\
\text { Accrediting } \\
\text { body }\end{array}$ & Duration & Assessment activities & $\begin{array}{c}\text { What each Case } \\
\text { highlights for } \\
\text { Assessment }\end{array}$ \\
\hline $\begin{array}{l}\text { Workplace } \\
\text { learning } \\
\text { facilitators }\end{array}$ & $\begin{array}{l}\text { Yes } \\
\text { IAL }\end{array}$ & $\begin{array}{l}10 \\
\text { months }\end{array}$ & $\begin{array}{l}\text { Formative assessment } \\
\text { from coaches } \\
\text { Summative assessment } \\
\text { through learning } \\
\text { journal, enterprise } \\
\text { report, and final } \\
\text { assessment interview } \\
70 \% \text { attendance } \\
\text { required }\end{array}$ & $\begin{array}{l}\text { Learning as "becoming" } \\
\text { through the achievement } \\
\text { of a set of competencies } \\
\text { which confer recognition } \\
\text { as a workplace learning } \\
\text { professional. }\end{array}$ \\
\hline $\begin{array}{l}\text { New } \\
\text { promotional } \\
\text { menu items }\end{array}$ & $\begin{array}{l}\text { No } \\
\text { N.A. }\end{array}$ & 4 weeks & $\begin{array}{l}\text { Live cooking } \\
\text { demonstration } \\
\text { Written feedback from } \\
\text { chef } \\
\text { Showing cooking team } \\
\text { how to cook new menu } \\
\text { items } \\
\text { Observation by outlet } \\
\text { supervisors after launch } \\
\text { of new menu items }\end{array}$ & $\begin{array}{l}\text { Learning of "aesthetic" } \\
\text { and "taste" is an integrated } \\
\text { and holistic process. The } \\
\text { knowledge \& skills cannot } \\
\text { be boiled down easily into } \\
\text { separate tasks. And } \\
\text { learning involves } \\
\text { development of learners' } \\
\text { judgment for his/her own } \\
\text { work. }\end{array}$ \\
\hline $\begin{array}{l}\text { Rota } \\
\text { commander }\end{array}$ & $\begin{array}{l}\text { Yes } \\
\text { WDA }\end{array}$ & 7 months & $\begin{array}{l}\text { Simulated exercises } \\
\text { Written theory tests } \\
\text { Presentations }\end{array}$ & $\begin{array}{l}\text { The learning of } \\
\text { "leadership" is about the } \\
\text { internalization of the ethos } \\
\& \text { values of the profession. } \\
\text { Learning is an embodied } \\
\text { process of doing, practice } \\
\text { and experience. }\end{array}$ \\
\hline $\begin{array}{l}\text { Resident } \\
\text { doctor }\end{array}$ & $\begin{array}{l}\text { Yes } \\
\text { Singapore } \\
\text { Medical } \\
\text { Council } \\
\text { ACGME-1 }\end{array}$ & 3 years & $\begin{array}{l}360 \text { feedback } \\
\text { Monthly evaluations } \\
\text { Mini CEX }\end{array}$ & $\begin{array}{l}\text { Learners have different } \\
\text { and sometimes conflicting } \\
\text { roles to fulfil as a } \\
\text { practicing doctor and } \\
\text { student. Any "new" } \\
\text { (formative) assessment }\end{array}$ \\
\hline
\end{tabular}


Ways in which learning spaces mediate learning and assessment

\begin{tabular}{|l|l|l|l|l|}
\hline Case & $\begin{array}{l}\text { Certified } \\
\text { Accrediting } \\
\text { body }\end{array}$ & Duration & Assessment activities & \multicolumn{1}{|c|}{$\begin{array}{c}\text { What each Case } \\
\text { highlights for } \\
\text { Assessment }\end{array}$} \\
\hline & & & & $\begin{array}{l}\text { tasks compete with other } \\
\text { priorities and needs. }\end{array}$ \\
\hline $\begin{array}{l}\text { Aircraft } \\
\text { engineer }\end{array}$ & $\begin{array}{l}\text { Yes } \\
\text { CAAS } \\
\text { WDA }\end{array}$ & 3 years & $\begin{array}{l}\text { Individual Final Year } \\
\text { Project } \\
\text { Summative assessment } \\
\text { through learning } \\
\text { journal, FYP report \& } \\
\text { final presentation }\end{array}$ & $\begin{array}{l}\text { Students' Final Year } \\
\text { Project requires } \\
\text { application of concepts \& } \\
\text { skills; have real work } \\
\text { utility \& suggests } \\
\text { complexity. It expands the } \\
\text { notion of "authenticity" } \\
\text { beyond just "real work". }\end{array}$ \\
\hline $\begin{array}{l}\text { IT Network } \\
\text { Engineers }\end{array}$ & $\begin{array}{l}\text { Yes } \\
\text { The } \\
\text { provider } \\
\text { WSQ } \\
\text { assessment } \\
\text { is optional }\end{array}$ & 1 week & $\begin{array}{l}\text { Observation of basic } \\
\text { skills by facilitator } \\
\text { Formative assessment } \\
\text { of problem solving } \\
\text { exercises } \\
\text { Written test involving a } \\
\text { range of network } \\
\text { problems to identify }\end{array}$ & $\begin{array}{l}\text { Learning \& assessment } \\
\text { focus on "ways of being" } \\
\text { an IT network engineer } \\
\text { that includes developing } \\
\text { analytical thinking for } \\
\text { problem solving, } \\
\text { developing understanding } \\
\text { of whole systems - global, } \\
\text { national and organisational } \\
\text { and in-between. }\end{array}$ \\
\hline
\end{tabular}

Table 1: The six case studies

IAL: Institute for Adult Learning; WDA: Workforce Development Agency; WSQ: Workforce Skills Qualifications (Singapore's competency-based training qualification system) 
Being a semi-ethnographic study our data consisted of semi-structured interviews, focus groups, observations and analysis of curriculum documentation and some assessment artefacts. We had a total of 105 pieces of data; discussions with participants in the observations are counted as part of the observation, not separately.

Interviews and focus groups were recorded and transcribed. The researchers read and reflected on these as the transcribing was completed. The transcriptions, documents and field notes from the observations were imported into NVIVO (software to assist with organising and analysing qualitative data). This data was then coded thematically using a process of selecting one case $(F \& B)$ for the initial development of the coding tree which involved all three researchers coding interview transcripts and observation notes of this case. The team met and used Kappa co-efficient score from NVIVO to flag out and focus discussion on different interpretations of the codes and data. The coding tree was refined and more detailed definitions of codes developed. The refined coding tree was used to re-code the F\&B case, followed by a research team meeting to compare again for further refinements before coding the remaining cases. For inter coder variability checks each case was assigned to a researcher who took charge of coding and writing that case. In addition the other two researchers analysed one or two transcripts/data sources of a case that was not their own. Researchers meet every fortnight to check interpretations and any emerging issues with consistency.

\section{Learning spaces for cooks in a restaurant chain}

This first story comes from the Food and Beverage $(F \& B)$ change in menu case study. This case study illustrates the practices and the relational aspects of learning spaces and how relations in this space are mediated by the mode of production and the staffing issues endemic in the sector. In illustrating practices and relational aspects of learning spaces we also highlight how work and learning inform each other, and the role assessment plays in enabling work and learning within the different learning spaces within the F\&B chain in Singapore, including a centralised kitchen and kitchens in the outlets.

Possibilities for learning in these spaces are mediated by the focus of the restaurant chain; that is, the food needs to be consistently the same in all the outlets and to facilitate this, as much as possible is prepared in the central kitchen and sent to the outlets (e.g. sauces, marinades, pre-prepared mixes, etc.), where cooks add the fresh ingredients. This mode of production is about ensuring consistent quality, presentation and taste across all the different outlets; there are elements of a 
production line here that mediate the purposes of training and place limits on the extent of development of the cooks.

To fulfil these needs, the restaurant chain conducts its own in-house training and assessment sessions for cooks who are deployed at the various restaurant outlets. The goals of training are to enable cooks to deliver the desired quality and consistent standards of newly launched menu items in a timely manner. The cooks at the outlet kitchens are expected to achieve the same aesthetic and taste criteria or standards as the Development Chefs (based in corporate headquarters) who design the menu as well as train and assess the cooks. The training goals and learning outcomes are conceived with fundamental business concerns in mind like meeting customers' needs, optimizing resources and minimizing costs, typical of this form of production. The thinking about learning outcomes begins at the stage of planning and designing of the new menu, and it rolls into training, assessment and final delivery of the new dishes. The training manager has to juggle between the different needs and priorities of the business, training/learning outcomes and the cooks' welfare. He continuously seeks different methods and ideas to develop and drive training/learning and assessment in the workplace. And the pragmatic approach that the training manager adopts for training/learning renders the learning space into a highly fluid and experimental one, yet what the cooks learn is in keeping with their role as production cooks in a chain producing the same dishes with consistent quality, appearance and taste. The form of production, then contributes to learning possibilities in the 'spaces' of this organisation. It also contributes to tensions that the training manager works with every day; on the one hand he needs compliance and staff who are trained to produce consistent standards, and on the other he constantly seeks how best to utilise the time and energy of his staff with their welfare in mind, but he is driven by company demands.

Because cooking is far more than following steps, assessment of and for the cooks seeks to engender professional 'senses' like taste and 'sensibility' including the dispositions, capacities and ethics for work in a professional kitchen. Developing taste proved problematic in the training taking place in the development kitchen, observed by the researchers; so much so that although it was an intended learning outcome, it was not assessed and barely touched upon in the training, thus there were missed opportunities for formative assessment of taste. Taste poses a challenge for assessment - what is 'taste'; how is it learned, and how can it be assessed? Taste as a form of knowledge highlights the different modes of knowing/learning involved in assessment. It cannot be boiled down to categories of skill and knowledge, and its learning cannot be easily distinguishable from the learner and that which is learned. Cooking like other types of skilled work such as masonry and carpentry are 'communicated, understood and negotiated between practitioners largely without words, and learning is achieved primarily through observation, mimesis and 
repeated exercise' (Marchand, 2008, p. 247). The 'know-how' of cooking is not easily conveyed through formal teaching/learning processes or outside of the professional kitchen setting. Much of what the chefs and cooks do, know and learn are tacit in nature - the work that they do and the knowledge they possess are intuitive, cannot be described easily, and is highly contextualised. These professional ways of knowing are an important aspect of learning spaces and are evident in the materiality of practices - as in the tools used, the sayings and doings of particular practices.

The vocation of cooking and its traditional ways of teaching and learning and the understandings of learning and assessment of the Development Chefs interact, in this instance, to close down possibilities for learning and formative and sustainable assessment. The development chefs had no pedagogical training or background so were reliant on using teaching methods as they were taught. Opportunities to discuss how the dishes the cooks had prepared tasted different and why, were perhaps not 'seen' as possibilities. Such a discussion potentially disrupts the power relation of master cook to apprentice. It places the Development Cooks, who may feel quite uncomfortable in managing a discussion that is not controllable, that may be exploratory, in an invidious position. When placed outside our comfort zones it is not unusual to resort to traditional forms of power relationships. To change this relationship would require developing the Chefs' pedagogical expertise, so see that opportunities to develop the language of taste as cooks tasted each other's dishes is an opportunity for learning and to achieve the desired learning outcome on taste. Such relational aspects of a learning space illustrate that historical ways of being, and the areas and degrees of expertise contribute to affordances (or not) for learning.

However, the taste aspect aside, the requirements of the work, and the structuring of the learning compelled active participation, engagement in meaningful activities, and the integration of learning with everyday work practices that achieves membership and recognition in one's work culture, organisation and/or community. Mulcahy (2011) comments on participatory aspects of learning and its role in integrating the individual into a particular community or communities.

'Underscored by the currently popular participatory or situated perspective on learning (Lave \& Wenger, 1991), explorations of how learning connects with work now tend to be made in terms of the concept of integrating the individual learner into the social participatory processes of a community of practice such as a workplace or a school community' (Mulcahy, 2011, p.205).

Communities operate within spaces and have within them and imposed upon them all the aspects of space discussed above, such as reflecting dominant discourses (or 
questioning of these) and ways of knowing that are an inherent part of the mode of production and of a given vocation or profession, cultural norms and ways of relating to each other. Training and assessment produce and re-produce these 'relational' aspects of learning spaces. For example, during our observation of the cooks being taught the new menu items in the central kitchen, we noticed the overall mood to be friendly, and the learners were cooperative and highly supportive of each other. There was an easy camaraderie (rather than competition) where the learners helped each other out with the smaller tasks such as washing the utensils, laying out the plates, and wiping off the kitchen counter. There is collective effort to help/enable performance during assessment. Training and assessment take into account the participatory nature of professional cooking and the requirements in the outlets of stepping in to help, where the training session taps on the camaraderie amongst cooks and close supervision by Development Chefs during assessment.

Through their participation in the training session, cooks concretise their leadership role because they are now responsible for teaching their colleagues in the outlet kitchens what they have learned at the company's centralised training kitchen. Cooks also saw themselves as valued employees because they have been identified for training at company headquarters. Therefore, training and assessment enable those cooks who have been 'selected' for training to enhance their status and membership within their respective outlet kitchen, and it also signals their integration into the company at large. These cooks are now full-fledged members of the 'community' of valued cooks within the company.

The assessment processes met three different but intertwined purposes: first, assessment functioned to enable accountability and compliance with company regulations. The assessment 'report' is proof that a staff member has been trained, so if a customer complains this is a source of information to analyse what the source of the problem might be. Additionally,

"it's also a deterrent for our operations and staff. The staff knows that somebody is watching so he/she jolly better be doing his/her job well, make sure that everything is properly done, this and that." (Charlie, Training Manager).

Second, assessment is envisaged to help or enable the cooks improve and/or become better in their job. Charlie the Training Manager expressed training and assessment to be developmental. He said, 'I always feel that once you train them, you assess them, (to me) assessment should be a build-up rather than a final sort of thing'. Third, Charlie highlighted issues about the 'loss' of know-how and investments made in learning/training when a trained staff leaves the company (this is an endemic issue within the F\&B sector in Singapore). Faced with these challenges, he 
surmised that the least training and assessment could do is to achieve its summative goals of testing and thereby making sure that the cooks are able to do their job. These purposes illustrate power relations within the learning spaces; they also illustrate Charlie's understanding of the purpose of assessment, what it is and how it should be conducted and who assesses. Here he seems to understand assessment as testing (not as judgement), that assessment takes place at the end, (i.e. assessment of learning). This is a common understanding of assessment. But interestingly Charlie, the training manager also very much understands assessment to be about performance - "making sure that the cooks are able to do their job". Not surprising then that although there was corrective feedback given to the cooks while they were preparing and cooking their dishes in the Development Kitchen, there was no sense of formative feedback and assessment (as in engaging in dialogue about what needed improving). Rather, the focus was on the summative assessment at the end of the day.

Understandings of learning and of assessment not only inform but contribute to the shaping of the spaces for learning. They inform actions and decisions about teaching strategies and techniques, roles of 'teacher' and learner, and the power relations between teacher and learner.

\section{Learning spaces for fire fighter leaders (Rota Commanders)}

This case highlights not only the relational features of learning spaces as discussed in the F\&B case, but also the temporal aspect of learning spaces, the role of tools and like the cooks, but more so, the ways of being that constitute learning spaces for these Rota Commanders in training.

In Singapore, the Civil Defence Academy under the Singapore Civil Defence Force (SCDF) conducts all professional and specialised training in the field of civil defence including disaster management, fire-fighting, urban search and rescue, detection and mitigation of hazardous materials and pre-hospital medical care operations. This is notable when we consider learning spaces, as the cultural norms and ways of being are of the Armed Forces, evident even in the term used to describe the learners - Officer Cadets. Officer Cadets are also inculcated as leaders formally through events like the Commissioning Parade and Oath Taking Ceremony. Events such as these are part of a ritual of participation and acceptance into a community of practice, which constitute another aspect of the learning space.

This 28-week program is divided into three phases: General, Professional and Command terms. Over the course and into their work as fire-fighters, a system of dispositions is developed and ways of thinking (Desmond, 2006) about danger such 
as running into a fire instead of away from it. Organisations like the Civil Defence Academy (CDA) builds, develops and conditions these dispositions by putting trainees through 'realistic training scenarios' using simulators like Liquid Petroleum Gas bullet tank fire simulator, oil tank fire simulator and high-rise building fire simulator affectionately called the 'Furnace'. These simulated spaces are important for introducing and developing Officer Cadets' to the doctrines and strategies of fire-fighting in ways that would be realistic and meaningful yet also provide a safer and controlled environment for learning. The dispositions and ways of thinking for an Officer Cadet in becoming a Rota Commander include leadership. Leadership is a fundamental aspect of a Rota Commander and it is inculcated throughout the Rota Commander program but also developed and taught more specifically as a job role and function in subjects such as 'Command and Control', which is further honed and assessed in 'Scenario Packages' and 'Command and Control Assessment' where field exercises are conducted in the simulators. To be a competent Rota Commander includes having the ability to read the ground well; to know what is happening at all times and be in control of the scene; to be able to make the right decisions promptly, and to persevere under duress and/or in extreme physical conditions. All these are perhaps better expressed in action and better understood in the future as the Officer Cadets grow into their role as Rota Commanders of the Singapore Civil Defence Force (SCDF). In the 28-week program, the Officer Cadets are taught fundamental skills, knowledge and strategies of fire-fighting; they familiarise themselves with the use of equipment and gain some exposure to the work of a Rota Commander during field exercises, and are enculturated into the officer corps of the SCDF. It is understood that the program prepares them for learning to become a Rota Commander upon graduation and placement. That is, the course provides preparation for undertaking this role but it is understood that it is only through experience that the Officer Cadets truly learn to become a Rota Commander. The Academy then is just one (but with multiple different learning spaces within it) of a series of learning spaces and events that the Rota Commanders would experience over time.

'Becoming' a Rota Commander for the Officer Cadets involves experiencing multiple learning spaces of classroom, fitness regimes and field exercises in different kinds of physical spaces and emergency situations like high-rise building fire, marine fire, chemical incident, traffic accident and so on. Rota Commanders are expected to lead their fire-fighters into these situations hence leadership is an important aspect of their training and work. Leadership is very much embodied; the journey to what it looks like, feels like, is developed over multiple simulated experiences in the Academy and this development continues well into their placement upon completion of the course and indeed over their careers. What we have observed during the field exercises and based on interviews with instructors 
and assessors is how aspects like leadership are not so easily distinguishable, and how the real essence or doctrine of leadership is expressed in action, and learned through demonstration.

"We [instructors and assessors] are driven by the final outcome which is to save lives. So there are times where I have to decide whether to carry the casualty out first or fight the fire. Because when I bring the casualty out, the fire is going to continue burning and grow bigger. So how do I balance these two decisions, and how far should I evacuate the casualty? So you need to be able to balance, and like I said it depends on the situation. The situation may be different but have you really seen that situation as it is - to understand the situation before you talk about deploying the men? So, these are skills that the Officer Cadets must have which they must demonstrate in every situation. The 'Appreciation of Situation' is fundamental to being a Rota Commander or a leader in the organization. It's a matter of fact so to speak - you have to. So, as a Rota Commander you must be able to justify your actions and we want the Officer Cadets to be able to do that." (MAJ Tom, Assessor).

Singapore is a highly urbanised and built-up city with a high population density. This geography of Singapore thus becomes part of the learning space for the structuring of the learning evident in 'High-Rise Fire' module being one of the most important modules in the Rota Commander program and it deeply permeates firefighting strategies. The module 'High-rise Fire' deals with fire incidences in 'HighRise Building' (HRB), and 'Super High-Rise Residential Building' (SHRB). Due to the height of these buildings which are beyond the reach of aerial and external firefighting approaches, the doctrine for fire-fighting in HRB and SHRB is typically limited to a strategy of 'internal fire-fighting' where fire-fighters must advance floor-by-floor through the heat and smoke to extinguish the fire. In this module, the Officer Cadets learn about High Rise Building/Super High Rise Building firefighting strategies and tactics. They engage in classroom learning, drills, and practice in simulation exercises at the 'Furnace'. In fire-fighting strategies and tactics, there are other more implicit qualities of performance that are essential which involves optimal utilisation of resources and manpower deployment, an alertness or situational awareness of the environment and knowledge of building/infrastructure systems.

It is evident that the learning space constitutes not only the physical space and its structures and arrangements, but the tools of fire-fighting strategies and 'tactics', ways of thinking about fires, dispositions, deployment of fire-fighters and how to track and manage them in addition to systems, and understanding the components 
and structures of buildings. There is a lot to learn about being in these spaces and doing the work that fire-fighters undertake in such spaces. However all this is but part of the space. In addition the Officer Cadets learn not just about the nuances of the work but they also "learn how to learn" from their instructors and assessors:

"The same guiding principle will guide you to do another job not because I tell you to but because you have the principle and guideline. We are not trying to be prescriptive because it is not possible to cover all scenarios or situations, so we go into guidelines to guide what they should do as a Rota Commander. We can tell them but they still cannot prepare - like for example one of the requirements is the ability to think on their feet" (MAJ Tom, assessor).

Officer Cadets need to be able to identify and prioritise tasks, and judge what the optimal level of resource and manpower utilisation is needed. Course designers, coordinators and instructors are cognisant of how professional competencies like responsiveness, alertness, awareness and decisiveness (or what instructors such as LTA Uma call 'street smart' or savviness) that involve combinations of tasks or activities, modes of understanding, interpreting and communicating, could be developed only with time and experience. This is another aspect of a temporal dimension in which the course at the Academy features as a moment in a series of learning spaces over the career of the Officer Cadet and/or Rota Commander in the SCDF.

From the Rota Commander case study we can understand learning and work as spaces that can be considered as an 'assemblage' or 'amalgam of places, bodies, voices, skills, practices, technical devices, theories, social strategies and collective work that together constitute...knowledge/practice' (Mulcahy, 2011, p.207). But it is also more than an assemblage of these things; it is the relations between them. Those relations are mediated by the cultural norms of command and control, not only within the Armed and/or Civil Defence Forces but necessary within high-risk work that requires split second decision making where lives are at risk. The nature of the profession, the vocation contributes to the space of learning, mediating what is learned and how it is learnt. 


\section{Conclusion}

We have used the two case studies discussed in this article to illustrate a) what constitutes learning spaces and b) to illustrate the potential of authentic and holistic learning and assessment that is conducted for, in and through work.

Learning spaces have a temporal aspect; they enable development of ways of "being" intrinsic to particular vocations and professions. Specifically learning spaces are inclusive of the practices within the space; the material things such as tools, the ways of thinking, the discourses, the doings, sayings and historicity of these practices, the individual biographies of those participating in the learning space. It is the relations between these aspects that are of particular interest in understanding what is happening. Additionally learning spaces interact with; indeed have embedded within them doings and sayings, discourses, affordances and constraints of the contexts which are also constituted by these dynamic interactions.

The Rota Commander story was illustrative of the temporal aspect of learning spaces, both cases made reference to ways of being for the vocation / profession that were evident in the interactions within the learning spaces. Indeed both stories illustrated that the body itself is a tool; for the cooks, taste as an aspect of the body, for the Rota Commanders, the senses used to 'read' the situation, the physical strength and dexterity required to use the equipment, so that correct use is like an extension of the body. Ways of being are integral to participating in and being accepted into a community of practice, as with the cooks being selected to learn and then teach others, the Rota Commanders participating in the ritual of the Commissioning Parade and Oath Taking Ceremony. But participation and acceptance is evident in much smaller ways, through for example feedback, not discussed here (see Bound, Chia \& Karmel, 2016), and of course taking active part in, being agentic within the exercises and other learning activities. The biographies of individuals were illustrated in the discussion of the Development Chef's pedagogical experience and their reliance on the way in which they were taught. Being part of a form of production (the cooks) or part of a professional body and institution such as the Singapore Civil Defence Force mediated learning spaces. The relations between all of these aspects enable us to analyse what is happening through a selected lens. In this Article, it is the lens of learning and assessment with a particular focus on authenticity.

Authentic learning and assessment such as for the cooks and Rota Commanders materialises learning as social practice. Authentic tasks may be defined as having "real-world relevance and utility"; "appropriate levels of complexity", and be "generative" (Herrington, Oliver \& Reeves, 2002, p.3). Authenticity takes on different forms, and happens in very different kinds of learning spaces reflective of the relevant ways of being; for the $\mathrm{F} \& \mathrm{~B}$ menu-change, training draws upon the 
resources of the professional kitchen and expertise of experienced chefs for summative-formative assessment, Officer Caders/learners in the Rota Commander course are engaged in a different but related form of real work through summative and formative simulation exercises. Authentic assessment refers to something more than its real-work setting and work/professional practice: actors particularly assessors, instructors and designers recognise the social dimensions of learning and assessment such as the mutually constitutive and dialogic nature of knowledge (Wells, 1999, p.75); collaborative aspect of work, and the holistic or "authentic wholeness" (Ross, 1999, p.154) of real work although assessment documentation and design often suggest otherwise (bound, Chia \& Karmel, 2016). Authenticity occurs "not in the learner, the task, or the environment, but in the dynamic interactions among these various components...authenticity is manifest in the flow itself, and is not an objective feature of any one component in isolation" (Barb, Squire \& Dueber 2000 in Herrington, Oliver \& Reeves, 2002, p.2).

The importance of "dynamic interactions" and "integratedness" of task, environment/setting and the learner as defining characteristics of authenticity introduce and/or shift the framework of investigating, analysing and understanding authentic assessment towards teaching/learning concepts like "situated learning", "communities of practice" and "legitimate peripheral participation" (Lave \& Wenger, 1991), which essentially theorise and authenticate learning as a social phenomenon. These concepts suggest a fundamental shift in focus towards the "nature and quality of the particular activities in which teachers and students participate together, and through which learning occurs" (Wells, 2000, p.75). Authentic assessment extends beyond "real work": it focuses on the quality of interactions that would enable learners' engagement; the dynamic interactions and integratedness between tasks, learners and the setting, and the application of concepts and skills, real world utility, complexity and generative-ness. All these suggest that authentic assessment enacts learning as social practice which takes into account factors like situatedness, community and participation. It is within the learning spaces that authentic assessment is enabled. 


\section{References}

Berry, R. (2008). Assessment for learning. Hong Kong: Hong Kong University Press.

Boud, D. (2000). Sustainable assessment: Rethinking assessment for the learning society. Studies in Continuing Education, 22(2), 151-167.

Boud, D., \& Soler, R. (2016). Sustainable assessment revisited. Assessment \& Evaluation in Higher Education, 41(3), 400-413.

Bound, H., \& Lin, M. (2010). Singapore Workforce Skills Qualifications (WSQ), Workplace Learning and Assessment (Stage One). Singapore: Institute for Adult Learning.

Bound, H., Sadik, S., \& Karmel, A. (2015). Developing non-permanent workers in Singapore. Singapore: IAL.

Bound, H., Chia, A. \& Karmel, A. (2016). Assessing learning for the changing nature of work. Singapore: Institute for Adult Learning, Singapore.

Brown, P., Lauder, H., \& Ashton, D. (2011). The global auction: the broken promises of education, jobs and incomes. New York: Oxford University Press.

Deming, D. (2015). The growing importance of social skills in the labor market. Working Paper 21473. http://www.nber.org/papers/w21473

Desmond, M. (2006) "Becoming a fire fighter" in Ethnography, 7(4), pp. 387-421.

Earl, L. (2003). Assessment as learning: Using classroom assessment to maximize student learning. Thousand Oaks, California: Corwin Press.

Edwards, R. \& Usher, R. (1996). What Stories Do I Tell Now? New times and new narratives for the adult education. International Journal of Lifelong Learning, 15(3), 216-229.

Engeström, Y. (2004). New forms of learning in co-configuration work. Journal of Workplace Learning, 16(1/2) 11-21.

Evans, K. \& Kersch, N. (2016). Understanding working places as learning spaces: perspectives, insights and some methodological challenges. ASEM Forum for Lifelong Learning 2016 21st Century Skills 3-5 October, Copenhagen.

Fenwick, T. (2000). Expanding conceptions of experiential learning: A review of the five contemporary perspectives on Cognition. Adult Education Quarterly, 50(4), 243-272.

Fenwick, T. (2004). Toward a critical HRD in theory and practice. Adult Education Quarterly, 54(3), 193-209.

Gardner, J. (2012). Assessment and learning: introduction. In J. Gardner (Ed.), Assessment and learning (2nd edition) (pp.1-9). London: Sage publications.

Hager, P., Lee, A., \& Reich, A. (2012). Problematising practice, reconceptualising learning and imagining change. In P. Hager, A. Lee \& A. Reich (Eds.), Practice, 
learning and change: Practice-theory perspectives on professional learning (pp.114). Dordrecht: Springer.

Herrington, J., Oliver, R., \& Reeves, T. (2002). Patterns of engagement in authentic online learning environments. In ASCILITE 2002 conference proceedings.

Lave, J., \& Wenger, E. (1991). Situated learning: Legitimate peripheral participation. Cambridge: Cambridge University Press.

Marchand, T. H. J. (2008). Muscles, morals and mind: craft apprenticeship and the formation of person. British Journal of Educational Studies, 56(3), 245-271.

Mulchay, D. (2011). Between work and learning: on pedagogic practice and interstitial space. Studies in Continuing Education, 33(3), 203-217.

Reckwitz, A. (2002). Towards a theory of social practices: a development in culturalist theorizing. European Journal of Social Theory, 5(2), 243-263.

Ross, M. (1999). Our hands will know: the development of tactile diagnostic skill teaching, learning and situated cognition in a physical therapy programme. Anthropology \& Education Quarterly, 30(20), 133-160.

Schatzki, T. (2012). A primer on practices: Theory and research. In J. Higgs et al (eds.) Practice-based Education Perspectives and strategies, pp.13-26.Rotterdam: Sense Publishers.

Straits Times (2015). 18 October "Future Economy".

Sfard, A. (1998). On two metaphors for learning and the dangers of just choosing one. Educational Researcher, 27(2) 4-13.

Shanmugaratnam, T. (2014). Speech by Deputy Prime Minister and Minister for Finance, Singapore at the Official Opening of the Lifelong Learning Institute. Retrieved from: http://www.mof.gov.sg/newsreader/articleid/1426/parentId/59/year/2014?category $=$ Speeches

Sung, J. et al (2010). Skills Utilisation Singapore: https://www.ial.edu.sg/files/ documents/399/You\%20and\%20Your\%20Work\%20Skills\%20Utilisation\%20 in\%20Singapore.pdf Accessed 20th October 2016.

Victor, B. \& Boynton, A. C. (1998). Invented here: Maximizing your organization's internal growth and profitability. Boston: Harvard Business School Press.

Wells, G. (1999). Dialogic Inquiry: towards a sociocultural practice and theory of education. New York: Cambridge University Press.

Wells, G. (2000). Dialogic inquiry in education: building on the legacy of Vygotsky. In C. D. Lee \& P. Smargorinsky (Eds.), Vygotskyian perspectives on literacy research (pp.51-85). New York: Cambridge University Press.

Zukas, M., \& Kilminster, S. (2012). Learning to practise, practising to learn: Doctors' transitions to new levels of responsibility. In P. Hager, R. A. Lee \& A. Reich (Eds.), Practice, learning and change: practice-theory perspectives on professional learning (pp. 199-213). Netherlands: Springer. 